\title{
The phenotype and genotype of rheumatoid arthritis in the Democratic Republic of Congo
}

\author{
JJ Malemba ${ }^{1 *}$, JM Mbuyi-Muamba ${ }^{1}$, J Mukaya ${ }^{2}$, X Bossuyt $^{3}$, MP Emonds ${ }^{4}$, K Deiteren $^{4}$, R Westhovens ${ }^{5}$ and \\ P Verschueren ${ }^{5}$
}

\begin{abstract}
Introduction: Little is known about rheumatoid arthritis in the black, particularly in Congolese, populations. Our objective was to describe the phenotype and genotype of rheumatoid arthritis (RA) in Congolese.

Methods: All consecutive rheumatoid arthritis (RA) patients attending Kinshasa University Hospital in a three-year time period were included. Demographics, clinical features and tobacco consumption were noted. Disease Activity Score (DAS)-28 based on the erythrocyte sedimentation rate (ESR), Health Assessment Questionnaire (HAQ), anticitrullinated peptide antibodies (CCP) antibodies and rheumatoid factor (RF) were determined. Radiographs were scored according to Sharp-van der Heijde. On a subset of patients and controls HLA-DRB1 typing was performed.

Results: A total of 114 females and 14 males aged $51.2 \pm 14.9$ were included. Mean duration of symptoms was four years. Moderate tobacco consumption was reported in a minority of patients. DAS-28 at first visit was $>5.1$ and $\mathrm{HAQ} \geq 0.5$ in all patients. X-rays showed joint erosions and/or joint space narrowing, mostly of a moderate grade in $55.8 \%$ of patients. Anti-CCP and/or RF were present in $48.6 \%$ of patients with available data $(n=72)$ and in $3.0 \%$ of controls $(n=67)$. Radiographic changes and nodules were more frequent in RF or anti-CCP positive patients. One copy of the shared epitope was found in 13 patients (35.1\%) and 3 controls (12.5\%). Two copies were found in one patient (2.7\%) and in one control (4.2\%).

Conclusion: Congolese patients with RA consult long after disease onset. Despite this delay, the majority presents without major damage and is RF, anti-CCP and SE negative. We put forward the hypothesis that besides different environmental factors there is probably also a particular genetic risk profile in Congolese patients, different from the HLA-DRB1 shared epitope.
\end{abstract}

Keywords: rheumatoid arthritis, phenotype, HLA-DRB1 genotype, DR Congo, Africa

\section{Introduction}

Rheumatoid arthritis (RA) is a systemic inflammatory disease characterized by symmetric destructive arthritis that is often associated with extra-articular and systemic manifestations. We must also take into account an important morbidity and socio-economic impact $[1,2]$ of this disease as well as an increased cardio-vascular mortality [3-6]. Great strides have been made on RA in recent years, including a better understanding of the genetic aspects, environmental factors and the disease's pathogenesis, at least in the Western world. These

\footnotetext{
* Correspondence: jeje_malemba2003@hotmail.com 'Department of Internal Medicine, Unit of Rheumatology, Kinshasa University Hospital, Kinshasa XI, Democratic Republic of Congo
} Full list of author information is available at the end of the article

(c) 2013 Malemba et al.; licensee BioMed Central Ltd. licensee BioMed Central Ltd. This is an Open Access article distributed under the terms of the Creative Commons Attribution License (http://creativecommons.org/licenses/by/2.0), which permits unrestricted use, distribution, and reproduction in any medium, provided the original work is properly cited. The Creative Commons Public Domain Dedication waiver (http://creativecommons.org/publicdomain/zero/1.0/) applies to the data made available in this article, unless otherwise stated. developments also concern the clinical approach, including methods used to assess the impact of RA as well as treatment principles, such as the early intensive therapy and treat-to-target approach, and the use of biologicals. In contrast, there are still few data on RA in many other parts of the world. Little is known about the epidemiology of RA in black Africa, its severity, the cross-cultural validity of the different classification criteria and measurement scores, the socio-economic aspects as well as the genetic and/or environmental factors leading to the disease. Therefore, just copying Western principles might not be correct.

In the Democratic Republic of Congo very few studies have been published on RA. In 2008, JJ Malemba and JM Mbuyi-Muamba reported, in a retrospective study, 
that RA was rare and mild in its clinical presentation at the University Hospital of Kinshasa (UHK) [7]. These observations were in agreement with those reported by Bwanahali et al. in 1995 [8]. But these studies did not use "quantifiable" parameters to assess the severity of RA, and the first mentioned study had a hiatus due to its retrospective nature. In addition, no information was given on the frequency of shared epitope (SE), smoking and the possible influence of a tropical environment with its specific background of infections. In a recent epidemiological study [9] also, a rather mild phenotype was suggested. The current study was initiated to describe prospectively the phenotype and HLA-DRB1 genotype of newly diagnosed RA patients attending the rheumatology unit of the UHK in order to assess the severity of the disease in this part of the world and to test the potential involvement of amino acids 70 to 74 in the third hypervariable region of HLA-DRB1 (SE).

\section{Materials and methods}

\section{Patient characteristics}

This study includes all patients who were received for the first time in the rheumatology unit of the UHK in the period from 1 January 2008 to 31 December 2010, and who fulfilled the 1987 American College of Rheumatology (ACR) classification criteria for RA [10]. The approval of the ethics committee of the University of Kinshasa and the consent of patients and controls were obtained. The UHK receives approximately 500 patients with rheumatic diseases (new cases) per year. Osteoarthritis is diagnosed in more than $50 \%$ of patients, systemic diseases, spondylarthropathies and crystal arthritis in approximately 25\% of patients, soft tissue rheumatism in 16\%, osteoporosis and septic arthritis are less frequent. The control group consisted of patients suffering from other rheumatic diseases (osteoarthritis, soft tissue rheumatism, osteoporosis): 59 women and 8 men aged between 18 and 74 years. The clinical evaluation involved general aspects (fever, weight loss), signs and localization of synovitis (small joints/large joints, symmetric or not) and the duration of morning stiffness. Typical joint deformities of RA were listed. Extra-articular manifestations were also checked, including rheumatoid nodules, sicca syndrome and symptoms of systemic manifestations like pericarditis and lung or pleural involvement. Tobacco consumption was registered. At the initial visit and before prescribing anti-rheumatic drugs, the Disease Activity Score (DAS-28) was calculated [11] as well as the Health Assessment Questionnaire (HAQ index) [12] to assess functional impairment. The DAS-28 calculation was based on the erythrocyte sedimentation rate after one hour. Items of the HAQ were explained and translated by the investigator whenever necessary. Radiographs of hands and feet in frontal plane were performed to evaluate joint space narrowing and erosions according to the Sharp score modified by van der Heijde [13].

\section{Detection of anti-citrullinated peptide antibodies and rheumatoid factor \\ Patient characteristics}

Blood samples were taken from a subset of the patients $(n=72)$ before the start of anti-rheumatic drugs and from controls $(n=67)$.

The samples were centrifuged at the time of collection and serum was stored at $-77^{\circ} \mathrm{C}$. The anti-citrullinated peptide antibodies (anti-CCP) were measured by fluoroenzyme immunoassay using reagents from the second generation (Thermo Fisher, Freiburg, Germany) on an Immuno CAP 250 instrument (Thermo Fisher). Rheumatoid factor (RF) was measured by nephelometry using an Immage 800 instrument (Beckman-Coulter, Brea, CA, USA) using reagents from Beckman-Coulter. Cutoff values for European individuals were applied.

\section{Hemoglobin concentration measurement}

The hemoglobin was measured in patients and controls by spectrophotometry using a molecular absorption spectrophotometer (SP 2100 Spectrum, CHINCAN; Shanghai, China).

\section{HLA-DRB1 genotyping and allele classification}

HLA-DRB1 typing was performed on a subset of patients $(n=37)$ and a control group $(n=24)$. Genomic DNA was extracted from EDTA peripheral blood samples with the QIAsymphony platform and the DNA Mini or Midi Kits (Qiagen, Hilden, Germany). HLADRB1 typing was performed using the sequence specific oligo (SSO) PCR technique (Lifecodes HLA-DRB1 typing kit, Gen-Probe, San Diego, CA, USA) with locus specific exon 2 amplification and hybridization on colored microbeads (Luminex, Austin, TX, USA). Alternatively a sequence specific primer (SSP) PCR method was used (HLA-DR low, Orelup, Vienna, Austria). Polymorphisms located in exon 3 were not resolved. The presence of shared epitope alleles was determined for patients and controls and the HLA-DRB1 alleles were classified according to du Montcel et al. [14]. This classification takes into account the amino acids 70 to 74 of HLA-DRB1. The highest risk for Caucasians was shown for the S2/S3P combination followed by S2/S2, S3P/S3P, $\mathrm{S} 2 \mathrm{~L}, \mathrm{~S} 3 \mathrm{P} / \mathrm{L}, \mathrm{L} / \mathrm{L}$ (in decreasing risk order). $\mathrm{L}$ is a combination group comprising the low risk groups S3D, S1 and $\mathrm{X}$.

\section{Statistical analysis}

A Student's $t$-test was used to compare data in patients with and without available data for X-ray damage, RF or anti-CCP. The odds ratios (OR) and the 95\% confidence intervals were calculated by logistic regression. Tests for association of contingency tables were performed using 
the two-tailed Fisher's exact test. A $P$-value $<0.05$ was considered statistically significant.

\section{Results}

One hundred twenty-eight patients were included, 114 women and 14 men (sex ratio F/M of 8:1). This study population represents $8.5 \%$ of all new patients attending the rheumatology unit of the UHK in the three-year study period. The clinical characteristics of the patients are described in Table 1 . The mean age of the patients was $51 \pm 14.9$ years (range 18 to 80 years). The average time between the onset of the symptoms and the first visit was four years (range two months to nine years), and the median delay was three years. Cigarette smoking was reported in a minority of patients (two males). Nine ladies reported to "snuff" tobacco powder through the nose. The DAS-28 at the first consultation was over 5.1 in all patients. A HAQ index $>0.5$ was reported in all but one patient. The average hemoglobin was $11.5 \pm 0.6 \mathrm{~g} / \mathrm{dl}$ for patients and $12.1 \pm 0.6 / \mathrm{dl}$ for the control group; 31 patients $(24.2 \%)$ had a hemoglobin concentration $\leq 10 \mathrm{~g} / \mathrm{dl}$. Rheumatoid nodules and typical joint deformities were found in $17(13.3 \%)$ and 28 patients (21.8\%), respectively, interosseous muscle atrophy in 20 patients $(15.6 \%)$, and sicca syndrome in 2 patients (1.6\%). Weight loss was mentioned by 60 patients (46.9\%).

Radiographs of hands and feet were obtained in a subgroup of patients only $(n=78)$. Forty-three $(55.1 \%)$ showed erosions and/or joint space narrowing. The average and median (P25, P75) values of the van der Heijde score were 17.6 and $2.5(0,13)$ respectively. A very high score ( $>100)$ was found in four patients. Anti-CCP antibodies and RF were measured in 72 patients and 67 controls. Anti-CCP antibodies were positive in 34 patients (47.2\%), RF in 25 patients (34.7\%), and 2 controls were anti-CCP+/RF+ (Table 2). Erosions and/or joint space narrowing were observed in $63 \%$ of anti-CCP positive patients whose X-ray of hands and feet were available, and in $54.3 \%$ of anti-CCP negative patients. A total of $11 /$ 13 patients with rheumatoid nodules had anti-CCP antibodies with very high titers (>300 U/1).

Table 1 shows that the patients whose serologic and/ or radiographic data were available were similar to those for whom these data were not obtained. All had symmetric arthritis, arthritis of hand joints and involvement of at least three joint areas. No statistically significant difference was observed between the average age of patients whose $\mathrm{X}$-rays were available compared to patients without X-rays $(P=0.21)$ or between patients with serological analyzes and patients without $(P=0.74)$.

HLA-DRB1 typing was performed in a subset of patients $(n=37)$ and controls $(n=24)$. The most frequent HLA-DRB1 alleles in the control group were HLA-DRB1*15:03, 13:01/02, 03:01/02 and 11:01. There was a very low carrier frequency of DRB1*04:01 and DRB1*13:03 in our Congolese population (patient group and controls). The SE alleles detected were DRB1*04:01, *13:03, "01:01/02 and *10. One copy of the SE was found in 13 patients (35.1\%) and 3 controls (12.5\%). Two copies of the SE were found in 1 patient $(2.7 \%)$ and 1 control (4.2\%).

The association of the anti-CCP, RF and HLA-DRB1 SE test with RA was calculated, as shown in Table 2. The RF and anti-CCP tests have a high specificity (true negatives) and positive predictive value (PPV) with an $\mathrm{OR}=17.3(P<0.0001)$ and $\mathrm{OR}=29.1(P<0.0001)$, respectively. However, the sensitivity and negative predictive value of these DNA tests are significantly lower. Although the HLA-DRB1 SE test had a specificity of $87 \%$ and a PPV of $81 \%$, the OR was only 3.8 (95\% CI 0.9 to 15.1$)(P=0.07)$. When the carrier status was counted, the OR was $2.6(95 \%$ CI 0.8 to 8.3$)(P=0.124)$. The classification of HLA-DRB1 alleles according to du Montcel et al. showed the rarity of S2 HLA-DRB1 alleles (Table 3). We also looked into the association between the presence of the SE together with anti-CCP antibodies or RF. Using an univariate regression analysis, the association between SE and RF or SE and anti-CCP antibodies could not be established $(P>0.05)$ (Table 4$)$.

\section{Discussion}

Our results indicate that in a three-year time period $8.5 \%$ of outpatients suffering from rheumatic diseases and attending the rheumatology unit of the UHK were diagnosed with RA. The relative RA frequency of $8.5 \%$ observed in this study is higher than that reported in a previous paper showing RA to affect $3.6 \%$ of the patients attending the rheumatology unit of UHK from 1988 to 2002 [7]. This is probably because of the retrospective nature of the latter study.

Table 1 Clinical characteristics of patients with X-ray and/or serology versus others

\begin{tabular}{llllll}
\hline Patients & Average age (years) & Disease duration & DAS-28 $>\mathbf{5 . 1}$ & Clinical presentation* $^{*}$ & Frequency of deformities \\
\hline Without X-ray & $53.3 \pm 16.0$ & $4.5 \pm 2.4$ & $100 \%$ & $100 \%$ & $21.6 \%$ \\
With X-ray & $49.9 \pm 14.0$ & $3.5 \pm 2.6$ & $100 \%$ & $100 \%$ & $22.0 \%$ \\
Without serology & $50.9 \pm 15.3$ & $4.1 \pm 2.8$ & $100 \%$ & $100 \%$ & $21.4 \%$ \\
With serology & $51.6 \pm 14.9$ & $3.9 \pm 2.9$ & $100 \%$ & $100 \%$ & $22.2 \%$ \\
\hline
\end{tabular}

$(*)$ : symmetric arthritis, hand joints involvement and involvement $\geq 3$ joint areas. DAS-28, Disease Activity Score 28 
Table 2 Test performance characteristics of SE, anti-CCP and RF for RA association

\begin{tabular}{|c|c|c|c|c|c|c|c|c|c|c|}
\hline Parameter & & $\begin{array}{l}\text { Patients } \\
\% \text { (n) }\end{array}$ & $\begin{array}{l}\text { Controls } \\
\% \text { (n) }\end{array}$ & PPV & NPV & Specificity & sensitivity & OR & $95 \% \mathrm{Cl}$ & $P$-value \\
\hline \multirow[t]{2}{*}{ SE } & positive & 35.1 (13) & $12.5(3)$ & 81 & 47 & 87 & 35 & 3.8 & 0.9 to 15.1 & 0.07 \\
\hline & negative & $64.9(24)$ & $87.5(21)$ & & & & & & & \\
\hline \multirow[t]{2}{*}{$\mathrm{RF}$} & positive & $34.7(25)$ & $3.0(2)$ & 93 & 58 & 97 & 35 & 17.3 & 3.9 to 76.6 & $<0.0001$ \\
\hline & negative & $65.2(47)$ & $97.0(65)$ & & & & & & & \\
\hline \multirow[t]{2}{*}{ anti-CCP } & positive & $47.2(34)$ & $3.0(2)$ & 94 & 63 & 97 & 47 & 29.1 & 6.6 to 127.9 & $<0.0001$ \\
\hline & negative & $52.7(38)$ & $97.0(65)$ & & & & & & & \\
\hline
\end{tabular}

Anti-CCP, anti-cyclic citrullinated peptide; NPV, negative predictive value; PPV, positive predictive value; RA, rheumatoid arthritis; RF, rheumatoid factor; SE, shared epitope

Patients consulted following a rather long delay after experiencing typical symptoms and all presented with a high value of DAS-28. This may be attributed to several factors: the poverty of the population with difficulties in accessing and paying for healthcare, the use of traditional medicine, and lack of information and education. It is, therefore, understandable why many patients consult only when symptoms become intolerable as a consequence of high disease activity. The high DAS-28-ESR scores in our patient population are probably partly related to the low hemoglobin level found in this study. These low hemoglobin levels may not necessarily be related to the severity of the RA since they are similar in patients and controls. They are probably influenced by the nutritional deficit and tropical infections which affect a part of the Congolese population. Therefore, it is probably unwise to compare DAS-28-ESR scores from Congolese patients in absolute terms with scores obtained in a Western population. We cannot exclude that DAS-28CRP would have allowed a more accurate interpretation of the disease activity, but unfortunately, for practical reasons, CRP could not be determined.

Mean HAQ index was rather high, probably related to the disease activity, but rheumatoid nodules and typical deformities were found in less than $20 \%$ of patients. Erosions and joint space narrowing were found in somewhat more than $50 \%$ of patients and were of low to moderate severity, taking into account the high disease activity and important delay before treatment.

The fact that more than $50 \%$ of Congolese RA patients are RF and anti-CCP negative may contribute to the mildness of the disease phenotype since the level of anti-CCP and RF titers is linked with the disease severity [15-17]. A mild phenotype was also reported in other African populations. Adewolo et al. [18] observed that in 200 patients followed for RA in Nigeria only $38.5 \%$ were RF positive and $29 \%$ had joint erosions on radiographs of hands, while the average duration of symptoms was 63 months before the first consultation. Ndongo S et al. [19] in Senegal reported that joint erosions were present in one-third of patients and that extra-articular manifestations were very rare, while the average time from the onset of symptoms to initiation of disease modifying antirheumatic drugs was 54 months. Anaya JM et al. [20] in Colombia have described that RA was less severe in blacks than Mestizos in terms of radiographic damage. Recently, SingweNgandeu et al. in Cameroon have also reported a mild presentation of RA among their patients [21].

$\mathrm{RF}$ and anti-CCP were observed in only a few controls $(2.98 \%)$ in our study, whereas in this population, higher numbers were expected due to the high frequency of parasitic and viral infections. Using European cut-off

Table 3 HLA-DRB1 alleles classified according to du Montcel et al.

\begin{tabular}{|c|c|c|c|c|c|c|c|c|}
\hline $\begin{array}{l}\text { du Montcel } \\
\text { classification }\end{array}$ & $\begin{array}{l}\text { Amino acid sequence positions } \\
\qquad 70 \text { to } 74\end{array}$ & HLA-DRB1 & $\begin{array}{l}\text { Patient group } \% \\
\text { (n) }\end{array}$ & $\begin{array}{l}\text { Controls \% } \\
\text { (n) }\end{array}$ & SE & OR & $95 \% \mathrm{Cl}$ & $P$-value \\
\hline \multirow[t]{2}{*}{ S2 } & QKRAA & ${ }^{*} 04: 01$ & $4.1(3)$ & $4.2(2)$ & positive & 2.6 & $\begin{array}{c}0.8 \text { to } \\
8.3\end{array}$ & 0.124 \\
\hline & DKRAA & *13:03 & & & & & & \\
\hline \multirow[t]{2}{*}{ S3P } & QRRAA & ${ }^{*} 01: 01 / 02$ & $14.9(11)$ & $4.2(2)$ & & & & \\
\hline & RRRAA & ${ }^{*} 10$ & & & & & & \\
\hline \multirow[t]{2}{*}{ S1 } & DERAA & $* 11: 02,{ }^{*} 13: 01 / 02$ & $81.0(60)$ & $91.6(44)$ & negative & & & \\
\hline & QARAA & *15 & & & & & & \\
\hline S3D & DRRAA & ${ }^{*} 11: 01, * 12, * 16$ & & & & & & \\
\hline$x$ & nonXXRAA & $\begin{array}{l}* 03,{ }^{*} 07,{ }^{*} 08,{ }^{*} 09, \\
{ }^{*} 14\end{array}$ & & & & & & \\
\hline
\end{tabular}

[14], in RA patients and controls (homozygous alleles are counted double)

OR, odds ratio; RA, rheumatoid arthritis; $S E$, shared epitope; $A$, alanin; $D$, aspartic acid aspartique; $E$, glutamic acid; $K$, leucin; $Q$, glutamin; $R$, arginin 
Table 4 Relation between shared epitope, anti-CCP and RF in Congolese RA patients

\begin{tabular}{|c|c|c|c|c|c|c|}
\hline & & \multicolumn{2}{|c|}{ RA patient group } & \multirow[t]{2}{*}{ OR } & \multirow[t]{2}{*}{$95 \% \mathrm{Cl}$} & \multirow[t]{2}{*}{$P$-value } \\
\hline & & SE positive & SE negative & & & \\
\hline \multirow[t]{2}{*}{ anti-CCP } & positive & 7 & 1 & 1.6 & 0.35 to 7.11 & 0.712 \\
\hline & negative & 4 & 10 & & & \\
\hline \multirow[t]{2}{*}{ RF } & positive & 4 & 9 & 0.76 & 0.17 to 3.4 & 1.0 \\
\hline & negative & 7 & 12 & & & \\
\hline
\end{tabular}

Anti-CCP, anti-cyclic citrullinated peptide; RA, rheumatoid arthritis; RF, rheumatoid factor

values for RF and anti-CCP antibodies, as done in this study, may be a problem in a sub-Saharan African population and for future studies it would be advisable to determine local cut-off values.

In our study there does not seem to be an association between the presence of the shared epitope and RF or anti-CCP antibodies (Table 4). Classic HLA-DRB1 S2 and S3P epitopes were very rare. Singwe-Ngandeu M et al. [21] observed also a discrepancy in a group of RA patients in Cameroon of whom more than $75 \%$ were RF positive and anti-CCP positive, but only $30 \%$ were carriers of the S2 and S3P HLA-DRB1 alleles. The four most frequent HLA-DRB1 alleles in our control group are those typically reported in sub-Saharan Africa [22].

Interestingly, there was a low prevalence of HLADRB1*04:01 in this study population (patients and controls) compared to other populations [23,24]. This observation is in agreement with that of Mbayo et al. [25,26], who reported that HLA-DR4 was less frequent in Congolese blood donors. This may be important since some authors have reported that HLA-DRB1*04:01 (S2) is associated with the most severe phenotype of RA [23,27]. Other HLADRB1 alleles, on the contrary, were more prevalent. In agreement with the study of Mbayo [25,26], we observed a high frequency of HLA-DRB1*15: 03 (X), DRB1*13:01/02 (S1) and DRB1*11:01 (S3D). The lower risk of these HLADRB1 alleles is confirmed in different studies [28-34].

The present study showed that $35.1 \%$ of the study RA population had S2 and S3P HLA-DRB1 alleles. However, compared to the control group, the association of SE with RA was statistically not significant. Singwe-Ngandeu et al. in Cameroon observed a lower frequency (30\%) of SE-positive cases among RA patients [21]. A low frequency of HLA-DRB1 SE in blacks was also observed by LB Hughes et al. [35], who reported a frequency of $25.2 \%$ in African American patients. They found a high degree of European ancestry among African Americans with SE alleles, which suggests that a genetic risk factor for RA was introduced into the African American population through admixture. This is not in agreement with the study of PWA Meyer et al. [36] who reported a frequency of $59 \%$ of high-risk SE alleles in a predominant black South African female population with RA, and this frequency is similar to that reported by Barnetche et al. in a
Caucasian population [37]. When considering our results, we cannot exclude that other genetic factors may be involved in Congolese RA patients. This needs further evaluation.

The effect of the environment on the incidence and phenotype of RA must also be considered. Smoking, the main environmental risk factor implicated in RA [38-40], is present only in a small proportion of our patients, and at a low level. Moreover, for cultural reasons women very rarely smoke in DR Congo. Beyond the effect of smoking, other environmental factors could be implicated. Previous studies conducted in sub-Saharan Africa have suggested a protective role of malaria against autoimmune diseases. This applies to the study of Greenwood [41] in Nigeria who observed that mice infected with Plasmodium falciparum showed fewer autoimmune disorders than mice free of P. falciparum. Similarly, Moolenburgh [42] in Lesotho observed that RA was more frequent and severe in areas of high altitude than on the warmer plains with more malaria. A similar survey in DR Congo could help to clarify this concept, and it remains to be seen whether the tropical environment with its many parasites could interfere with the phenotype of RA or be implicated in the pathogenesis of the disease.

Disease classification, disease activity and functionality of RA were evaluated in this paper using standardized methods that are classical for evaluation of patients seen in the Western world. Unfortunately, mainly because of the cost issue, detailed serology data and genetic typing were not feasible in all patients. Nevertheless, this study will provide a benchmark for measuring benefits of RA care in central Africa and will allow comparing disease patterns in rural compared to this urban population in the future. These preliminary results also make clear that perhaps specific validation is needed for classification criteria outside the Western world. For instance, the very recent new classification criteria for RA [43] are of no use in a specific situation where CRP and CCP measurement is not performed in daily practice and where intensive treatment and a treat-to-target approach are currently unrealistic goals. We also found aspects of timing (duration of morning stiffness, six weeks symptom duration) sometimes problematic to evaluate, as time 
perceptions are different compared to the Western world. Also proper cross-cultural validation of instruments like the HAQ needs to be carried out, not only because of translation issues, but also because of content problems; for instance, with concepts like 'shampooing hair' which is not often done by Congolese women.

\section{Conclusion}

In conclusion, the current preliminary data on the phenotype and genotype of RA are the first from this part of the world and according to our findings, we put forward the hypothesis that the particular genetic profile of RA in Western Europe is not present in subSaharan Africans and this could explain the decreased severity of the disease. A study in a larger sample population is needed to better assess the impact of HLA-DRB1alleles on the prevalence and phenotype of RA in Congolese, and the correlation between the shared epitope and the presence and titers of anti-CCP and RF.

\begin{abstract}
Abbreviations
ACR: American College of Rheumatology; Anti-CCP antibody: anti-cyclic citrullinated peptide antibody; DAS-28-ESR: Disease Activity Score 28 based on the erythrocyte sedimentation rate; EDTA: ethylene diamine tetra acetic acid; F: female; HAQ: Health Assessment Questionnaire; HILA:

Histocompatibility and Immunogenetics Laboratory; HLA: human leucocyte antigen; M: male; OR: odds ratio; PCR: polymerase chain reaction; PPV: positive predictive value; RA: rheumatoid arthritis; RF: rheumatoid factor; SE: shared epitope; SSO: sequence specific oligonucleotide; SSP: sequence specific primer; UHK: University Hospital of Kinshasa
\end{abstract}

\section{Competing interests}

The authors declare that they have no competing interests.

\section{Authors' contributions}

JJM conceived of the study, participated in its design and coordination, and helped to draft the manuscript, JMM conceived of the study, participated in its design and coordination, and was involved in revising the manuscript. JM performed and scored the $\mathrm{X}$-rays and was involved in revising the manuscript. XB was responsible for the determination of RF on anti-CCP antibodies and helped to draft the manuscript. MPE and KD were responsible for HLA typing and helped to draft the manuscript. RW and PV conceived of the study, participated in its design and coordination, and helped to draft the manuscript. All authors read and approved the final manuscript.

\section{Acknowledgements}

This work has been partly funded by the non-restricted "Pfizer Travel Grant $2010^{\prime \prime}$ from the FWRO-FRSR of the Royal Belgian Society of Rheumatology.

\section{Authors' details}

'Department of Internal Medicine, Unit of Rheumatology, Kinshasa University Hospital, Kinshasa XI, Democratic Republic of Congo. 'Unit of Radiology, Kinshasa University Hospital, Kinshasa XI, Democratic Republic of Congo. ${ }^{3}$ Experimental Laboratory Immunology, Department of Medical Diagnostic Sciences, KU Leuven, Belgium. ${ }^{4}$ Histocompatibility and Immunogenetics Laboratory (HILA), Red Cross Flanders, Mechelen, Belgium. ${ }^{5}$ Division of Rheumatology, Department of Development and Regeneration, Neuromusculo-Skeletal Research Unit, KU Leuven, Belgium.

Received: 16 October 2012 Revised: 28 February 2013 Accepted: 19 August 2013 Published: 19 August 2013
References

1. Cooper NJ: Economic burden of rheumatoid arthritis: a systematic review. Rheumatology 2000, 39:28-33.

2. Westhovens R, Boonen A, Verbruggen L, Durez P, De Clerck L, Malaise M, Mielants H: Healthcare consumption and direct costs of rheumatoid arthritis in Belgium. Clin Rheumatol 2005, 24:615-619.

3. Levy L, Fautrel B, Barnetche T, Schaeverbeke T: Incidence and risk of fatal myocardial infarction and stroke events in rheumatoid arthritis patients. A systematic review of the literature. Clin Exp Rheumatol 2008, 26:673-679.

4. Meune C, Touze E, Trinquart L, Allanore $Y$ : Trends in cardiovascular mortality in patients with rheumatoid arthritis over 50 years: a systematic review and meta-analysis of cohort studies. Rheumatology 2009, 48:1309-1313.

5. Maradit-Kremers H, Nicola PJ, Crowson CS, Ballman KV, Gabriel SE: Cardiovascular death in rheumatoid arthritis: a population-based study. Arthritis Rheum 2005, 52:722-732.

6. Nicola PJ, Crowson CS, Maradit-Kremers H, Ballman KV, Roger VL, Jacobsen SJ, Gabriel SE: Contribution of congestive heart failure and ischemic heart disease to excess mortality in rheumatoid arthritis. Arthritis Rheum 2006, 54:60-67.

7. Malemba JJ, Mbuyi-Muamba JM: Clinical and epidemiological features of rheumatic diseases in patients attending the university hospital in Kinshasa. Clin Rheumatol 2008, 27:47-54.

8. Bwanahali K, Mbuyi M, Kapita B: Osteoarthrosis, gout and arthritis rheumatoid in internal medicine in Kinshasa. Rev Rhum Mal Osteoartic 1991, 58:105-111.

9. Malemba JJ, Mbuyi-Muamba JM, Mukaya J, Bossuyt X, Verschueren P, Westhovens R: The epidemiology of rheumatoid arthritis in Kinshasa, Democratic Republic of Congo-a population-based study. Rheumatology 2012, 51:1644-1647.

10. Arnett FC, Edworthy SM, Bloch DA, McShane DJ, Fries JF, Coopper NS, Healey LA, Kaplan SR, Liang MH, Luthra HS, Medsger TA Jr, Mitchell DM, Neustadt DH, Pinals RS, Schaller JD, Sharp JM, Wilder RL, Hunder GG: The American Rheumatism Association 1987 revised criteria for the classification of rheumatoid arthritis. Arthritis Rheum 1988, 31:315-324.

11. Prevoo ML, van't Hof MA, Kuper $H H$, van Leeuwen $M A$, van de Putte $L B$, van Riel PL: Modified disease activity scores that include twenty-eightjoint counts. Development and validation in a prospective longitudinal study of patients with rheumatoid arthritis. Arthritis Rheum 1995, 38:44-48.

12. Guillemin F, Braincon S, Pourel J: Measurement of the functional capacity in rheumatoid polyarthritis: a French adaptation of the Health Assessment Questionnaire (HAQ). Rev Rhum Mal Osteoartic 1991 58:459-465.

13. van der Heijde D: How to read radiographs according to the Sharp/van der Heijde method. J Rheumatol 1999, 26:743-745.

14. du Montcel ST, Michou L, Petit-Teixeira E, Osorio J, Lemaire I, Lasbleiz S, Pierlot C, Quillet P, Bardin T, Prum B, Cornelis F, Clerget-Darpoux F: New classification of HLA-DRB1 alleles supports the shared epitope hypothesis of rheumatoid arthritis susceptibility. Arthritis Rheum 2005, 52:1063-1068.

15. Turesson C, Jacobsson LT, Sturfelt G, Matteson EL, Mathsson L, Rönnelid J: Rheumatoid factor and antibodies to cyclic citrullinated peptides are associated with severe extra-articular manifestations in rheumatoid arthritis. Ann Rheum Dis 2007, 66:59-64.

16. Agrawal S, Misra R, Aggarwal A: Autoantibodies in rheumatoid arthritis: association with severity of disease in established RA. Clin Rheumatol 2007, 26:201-204.

17. Berglin E, Johansson T, Sundin U, Jidell E, Wadell G, Hallmans G, RantapääDahlqvist S: Radiological outcome in rheumatoid arthritis is predicted by presence of antibodies against cyclic citrullinated peptide before and at disease onset, and by IgA-RF at disease onset. Ann Rheum Dis 2006, 65:453-458.

18. Adelowo OO, Ojo O, Oduenyi I, Okwara CC: Rheumatoid arthritis among Nigerians: the first 200 patients from a rheumatology clinic. Clin Rheumatol 2010, 29:593-597.

19. Ndongo S, Lekpa FK, Ka MM, Ndiaye N, Diop TM: Presentation and severity of rheumatoid arthritis at diagnosis in Senegal. Rheumatology 2009, 48:1111-1113.

20. Anaya JM, Correa PA, Mantilla RD, Jimenez F, Kuffner T, McNicholl JM: Rheumatoid arthritis in African Colombians from Quibdo. Semin Arthritis Rheum 2001, 31:191-198. 
21. Singwe-Ngandeu M, Finckh A, Bas S, Tiercy JM, Gabay C: Diagnostic value of anti-cyclic citrullinated peptides and association with HLA-DRB1 shared epitope alleles in African rheumatoid arthritis patients. Arthritis Res Ther 2010, 12:R36.

22. Middleton $D$, Menchaca $L$, Rood $H$, Komerofsky R: New allele frequency database. Tissue Antigens 2006, 61:403-407.

23. Pascual M, Nieto A, Lopez-Nevot MA, Ramal L, Mataran L, Caballero A Alonso A, Martin J, Zanelli E: Rheumatoid arthritis in southern Spain: toward elucidation of a unifying role of the HLA class II region in disease predisposition. Arthritis Rheum 2001, 44:307-314.

24. Collins MM, Tang T, Slack R, Sintasath D, Hartzman RJ, Nq J, Hurley CK: The relative frequencies of HLA-DRB $1 * 01$ alleles in the major US populations. Tissue Antigens 2000, 55:48-52.

25. Mbayo K: Etude du système HLA dans la population congolaise et ses implications dans les maladies auto-immunes. 1999, Thèse PhD, Université de Kinshasa; Département de Biologie médicale.

26. Mbayo K, Mbuyi-Muamba JM, Lurhuma A, Halle L: HLA-DR gene frequencies in a Zairean population with particular reference to rheumatic diseases. Clin Rheumatol 1998, 17:105-109.

27. Gonzalez-Gay MA, Garcia-Porrua C, Hajeer AH: Influence of human leukocyte antigen-DRB1 on the susceptibility and severity of rheumatoid arthritis. Semin Arthritis Rheum 2002, 31:355-360.

28. van der Helm-van Mil AH, Huizinga TW, Schreuder GM, Breedveld FC, de Vries RR, Toes RE: An independent role of protective HLA class II alleles in rheumatoid arthritis severity and susceptibility. Arthritis Rheum 2005, 52:2637-2644.

29. Citera G, Padulo LA, Fernandez G, Lazaro MA, Rosemffet MG, Maldonado Cocco JA: Influence of HLA-DR alleles on rheumatoid arthritis: susceptibility and severity in Argentine patients. J Rheumatol 2001, 28:1486-1491.

30. Delgado-Vega AM, Anaya JM: Meta-analysis of HLA-DRB1 polymorphism in Latin American patients with rheumatoid arthritis. Autoimmun Rev 2007, 6:402-408.

31. Holoshitz J: The rheumatoid arthritis HLA-DRB1 shared epitope. Curr Opin Rheumatol 2010, 22:293-298.

32. van der Horst-Bruinsma IE, Visser H, Hazes JM, Breedveld FC, Verduyn W, Scheuder GM, de Vries RR, Zanelli El: HLA-DQ-associated predisposition to and dominant HLA-DR-associated protection against rheumatoid arthritis. Hum Immunol 1999, 60:152-158.

33. Lundstrom E, Kallberg H, Smolnikova M, Ding B, Rönnelid J, Alfredsson L, Klareskog L, Padyukov L: Opposing effects of HLA-DRB1*13 alleles on the risk of developing anti-citrullinated protein antibody-positive and anticitrullinated protein antibody-negative rheumatoid arthritis. Arthritis Rheum 2009, 60:924-930.

34. Seidl C, Körbitzer J, Badenhoop K, Seifried E, Hoelzer D, Zanelli E, Kaltwasser JP: Protection against severe disease is conferred by DERAAbearing HLA-DRB1 alleles among HLA-DQ3 and HLA-DQ5 positive rheumatoid arthritis patients. Hum Immunol 2001, 62:523-529.

35. Hughes LB, Morrison D, Kelley JM, Padilla MA, Vaughan LK, Westfall AO, Dwivedi H, Mikuls TR, Holers VM, Parrish LA, Alarcón GS, Conn DL, Jonas BL, Callahan LF, Smith EA, Gilkeson GS, Howard G, Moreland W, Patterson N, Reich D, Bridges SL Jr: The HLA-DRB1 shared epitope is associated with susceptibility to rheumatoid arthritis in African Americans through European genetic admixture. Arthritis Rheum 2008, 58:349-358.

36. Meyer PW, Hodkinson B, Ally M, Musenge E, Fickl H, Tikly M, Anderson R: HLA-DRB1 shared epitope genotyping using the revised classification and its association with circulating autoantibodies, acute phase reactants, cytokines and clinical indices of disease activity in a cohort of South African rheumatoid arthritis patients. Arthritis Res Ther 2011, 13 . R160.

37. Barnetche T, Constantin A, Cantagrel A, Cambon-Thomsen A, Gourraud PA: New classification of HLA-DRB1 alleles in rheumatoid arthritis susceptibility: a combined analysis of worldwide samples. Arthritis Res Ther 2008, 10:R26.

38. Baka Z, Buzas E, Nagy G: Rheumatoid arthritis and smoking: putting the pieces together. Arthritis Res Ther 2009, 11:238.

39. Bang SY, Lee KH, Cho SK, Lee HS, Lee KW, Bae SC: Smoking increases rheumatoid arthritis susceptibility in individuals carrying the HLA-DRB1 shared epitope, regardless of rheumatoid factor or anti-cyclic citrullinated peptide antibody status. Arthritis Rheum 2010, 62:369-377.
40. Too CL, Yahya A, Murad S, Dhaliwal JW, Larsson PT, Muhamad NA, Mustafa AN, Klareskog L, Alfredsson L, Padyukov L, Bengtsson C, MyEIRA study group: Smoking interacts with HLA-DRB1 shared epitope in the development of anti-citrullinated protein antibody-positive rheumatoid arthritis: results from the Malaysian Epidemiological Investigation of Rheumatoid Arthritis (MyEIRA). Arthritis Res Ther 2012, 14:R89.

41. Greenwood BM: Autoimmune disease and parasitic infections in Nigerians. Lancet 1968, 7564:380-382.

42. Moolenburgh JD, Valkenburg HA, Fourie PB: A population study on rheumatoid arthritis in Lesotho, southern Africa. Ann Rheum Dis 1986, 45:691-695.

43. Aletaha D, Neogi T, Silman AJ, Funovits J, Felson DT, Bingham CO, Birnbaum NS, Burmester GR, Bykerk VP, Cohen MD, Combe B, Costenbader KH, Dougados M, Emery P, Ferracioli G, Hazes JM, Hobbs K, Huizinga TW, Kavanaugh A, Kay J, Kvien TK, Laing T, Mease P, Ménard HA, Moreland LW, Naden RL, Pincus T, Smolen JS, Stanislawska-Bienart E, Symmons D, et al: 2010 rheumatoid arthritis classification criteria: an American College of Rheumatology/European League Against Rheumatism collaborative initiative. Ann Rheum Dis 2010, 69:1580-1588, Erratum in Ann Rheum Dis 2010, 69:1892.

doi:10.1186/ar4269

Cite this article as: Malemba et al.: The phenotype and genotype of rheumatoid arthritis in the Democratic Republic of Congo. Arthritis Research \& Therapy 2013 15:R89.

\section{Submit your next manuscript to BioMed Central and take full advantage of:}

- Convenient online submission

- Thorough peer review

- No space constraints or color figure charges

- Immediate publication on acceptance

- Inclusion in PubMed, CAS, Scopus and Google Scholar

- Research which is freely available for redistribution

Submit your manuscript at www.biomedcentral.com/submit
Ciomed Central 